\title{
はじめに
}

挿耳形補聴器の使用率が高まり，社会的にも定着してきていることを反映して，高齢者 の場合でも，小型であることや目立たないことなどを理由に、挿耳形補聴器のニードは強 くなってきている。われわれは, 高齢者にとって操作性に難点がある挿耳形補聴器の操作 性を改善するために, 最近開発されたKアンプを使用した補聴器を使い, ボリューム（利 得調整器) を外した挿耳形補聴器を作成し, 老人難聴者に適応を試みたので報告する。 目 的

Kアンプを使用した補聴器は, 入力音圧によって高音域の利得が変化し, 小さい入力音 圧では利得が高く, 大きい入力音圧では利得が低くなる特性を持っている。我々はこの特 性を利用し, 補聴器の利得調整器を半固定のトリマーにすることで, 比較的軽度の難聴者 あれば, 利得調整器の操作から解放され, 高齢者でも挿耳形補聴器の適応性が高まると考 え検討を行った。

方法

4 名の老人難聴者( 既に挿耳形補聴器を使用している者 2 名, 補聴器初めて装用する者 2名)に，Kアンプを使用した插耳形（オーダーメイド）を作製し，音場による検査と生 活場面での聴取の様子について聞き取り調査を行った。

音場の検査は, リオン社製オージオメータAA-63BNのバンドノイズを自動断続器を通し て使用し, 増幅器とアッテネータを経て、スピーカーより出カした。アッテネータと增幅 器はリオン社製総合聴力検査装置 (MA-71A) を使用した。アッテネータは $5 \mathrm{~dB}$ と $1 \mathrm{~dB}$ を併 用し測定した。

日常の場面での聴取の様子については, 装用開始から 3 週間程度で, 面接での聞き取り 調査を行なった。

結果

(症例 1 )

75 歳男性。感音難聴。平均聴カレベル, 右 $30 \mathrm{~dB}$, 左 $43 \mathrm{~dB}$ 。内部障害による身体障害者 手帳を所持。身体障害者団体の役員, 民生委員等を歴任しているために会議が多く, 数年 前より難聴を自覚。小さめの会話が聞き取りにくくなり, 半年ほど前より左耳に插耳形補 聴器 (レディーメイド形) を使用してきた。

装用域值はKアンプと普通アンプとを比べると，Kアンプの方がょり低い值を示した。 特に, 高音域の方がその傾向が強かった。

装用状況の比較では, Kアンプ式のものは, 畳の擦れる音, 紙をなでる音などの小さい 音が大きく聞こえて驚くことがあるとのことであった。会議などの離れた声や声の小さな 人との会話は，Kアンプの方が聞き取りやすいとの回答を得た。

利得調整器が無い点については, 殆どの状況で不便さは感じなかったが, 今まで聞こえ なかった小さな音が聞こえてしまうことに慣れていないので，音を下げておきたいときに ボリュームがないのは不安があるとの回答を得た。 


\section{(症例 2)}

65 歳男性。2 0 年ほど前から難聴になる。感音難聴。平均聴力レベル, 右 $41 \mathrm{~dB}$, 左 51 $\mathrm{d} B, 15$ 年前から耳掛け形の補聴器を装用し，4年前から挿耳形補聴器（オーダーメイド 形)を使用してきた。事務系の仕事に現在も従事している関係で, 補聴器は常用している。 装用域値は低音域では普通アンプの方が低い値を示したが, 高音域でKアンプの方が低 い値を示した。

装用状況では，Kアンプは小さな物音をよく拾ってしまうが，離れた言葉が聞きやすい， 小さい声での話が聞きやすいとの回答を得た。また，車の騒音などがあるうるさい環境の 中でも言葉が聞き取りやすく, 普通アンプよりは聞き取りは良いとの事であった。

ボリュームの無いことについては, 今までは相手の声の大きさによって,ボリュームを 頻繁に動かしていたが，Kアンプでは殆どの場面でボリュームを動かす必要を感じなかっ たとのことであった。

(症例 3 )

80 歳女性。5 6 年前から難聴を自覚。補聴器の装用歴は無い。対面の会話でも声が 小さいと聞き洩らしが增えて来たので補聴器を装用したいと来所。感音難聴。平均聴力レ ベル, 右 $60 \mathrm{~dB}$, 左 $30 \mathrm{~dB}$ 。右耳に装用を行なった。

装用後, 老人会の会議での離れた発言が聞きやすくなった, テレビの聴取が家族と同じ ボリュームで可能になった，人の名前などの固有名詞の聞き誤りが減少したなどの改善が みられた。

ボリュームの無い点については, 初めての装用であることもあって, 特に不便さは感じ なかったとの事であった。装着して,スイッチを入れるという操作だけなので,すぐに自 分だけで装用が可能になった。

(症例 4)

87 歳女性。家族が皆小声で話すので聞き取りにくいとの訴えで来所。感音難聴。平均 聴力レベル右 $35 \mathrm{~dB}$, 左 $45 \mathrm{~dB}$ 。左耳にKアンプ補聴器を装用する。

家族との会話で緊張して聞くことがなくなり楽になった。テレビの聴取が家族と同じボ リュームで聞き取れるようになった。教会で牧師さんの説教が離れていても，良く聞こえ るようになったなどの回答をえた。

ボリュームが無いことについては症例 3 と同様に, 初めての装用のためと思われたが, 特に不便さは感じないとの回答であった。

まとめ

老人難聴者に挿耳形補聴器の操作性を改善する目的で, Kアンプ形の補聴器を利得調整 器を半固定トリマーで作製し, 装用状態を検討した。症例数が少ないが, 概ね良好な結果 を得た。

普通の補聴器の装用歴のある場合には, ボリュームの無いことへの不安を訴える症例が あったが, 日常生活の殆どの場面で, 適応が可能であるように思われた。

Kアンプの特性である小さい会話などでの聞き取りのよさは, 4 症例とも報告しており, 軽度の難聴者での適応は高いと思われた。

更に症例を增やして検討を進めたいと考えている。 